\title{
Introduction to the Special Issue on Indigenous and Afrodescendant Movements and Organizations in Latin America: Negotiating, Resisting, Performing and Re- purposing Dominant Categories ${ }^{2}$
}

\section{Introduction}

In 2018 the Albert Hirschman Centre on Democracy in Geneva organized together with Europaeum and Alternautas, the workshop on "Democracy, Indigenous Rights and Ethno-Racial Mobilization: Latin America in Comparative Perspective." This workshop was part of the "Geneva Democracy Week" organized by the Geneva Chancellery of State to promote dialogue between political institutions, civil society, students and citizens, with a view to strengthening their participation in democratic processes. Our focus on Indigenous and Afrodescendant movements was intended to illuminate the ongoing contributions these populations have made to expanding and redefining democracy. Latin America has been the site of inspiring activism over the last decades, as formerly subaltern populations have challenged the ongoing legacies of colonialism and claimed citizenship rights. We

\footnotetext{
${ }^{1}$ DIEGO SILVA is a Postdoctoral Research Associate at the Albert Hirschman Centre on Democracy in Geneva, and NANCY POSTERO is the Co-Director of the Human Rights Program at UC San Diego and is the Co-Director of the International Institute.

${ }^{2}$ This article was originally published in: http://www.alternautas.net/blog/2020/8/7/introduction-to-the-special-issue-on-indigenousand-afrodescendant-movements-and-organizations-in-latin-america-negotiating-resistingperforming-and-re-purposing-dominant-categories
} 
received paper proposals from students of different European universities in Switzerland, England, Germany and Luxemburg and selected nine papers to be discussed at the workshop on the $6^{\text {th }}$ of October at the Graduate Institute of International and Development Studies. The papers received feedback from the workshop conveners, Graziella Moraes, Filipe Calvão and Diego Silva from the Graduate Institute in Geneva, as well as from our special guests Nancy Postero, professor UC San Diego, Ethel Branch, former Attorney General of the Navajo Nation and Karmen Ramirez Bóscan, founder of Wayunkerra Indigenous Women's Initiative in Guajira Colombia, as well as anonymous peer review. Thus, the articles in this special issue of Alternautas are the product of a rich international conversation.

At the time of the workshop, Evo Morales was still in power in Bolivia, the 2019 Indigenous protests in Ecuador had not taken place, Chilean citizens had not massively mobilized against the unfulfilled promises of neoliberal development, and more than 350 Colombian activists, including many Indigenous and Afrodescendant leaders, had not been assassinated. Thus, workshop participants did not focus on these dramatic events but considered the long-term colonial structures that still permeate international institutions, the State and the market. Today we can reflect on how these contributions dialogue with the 2019 period of social unrest in Latin America. Thus, in this introduction we first discuss the questions addressed by contributors to this special issue, to then focus on some of the ideas that contributors raise in the light of more recent events.

\section{Dominant Categories}

Starting in the 1980s, Indigenous and Afrodescendant communities began to organize and mobilize, claiming rights to citizenship and equal participation in the nation-states where they live. Across the continent, these civil society organizations marched, protested, held hunger strikes, blockaded highways, calling for inclusion in the democratic societies where they live. As a result, during the 1990s, the socalled Latin American "multicultural turn" gave rise to reforms of national constitutions intended to grant inclusion of Indigenous communities and 
Afrodescendant populations in political and social processes (Cottrol and Hernandez, 2001, Seider 2002, Van Cott, 2000). These legislative reforms included collective territorial titling, bilingual and intercultural education reform, cultural and linguistic recognition, and measures to insure political participation (see Postero 2007). However, the actions of Indigenous peoples' and Afrodescendant social movements/organizations in Latin America are embedded within and limited by a set of disciplinary and regulatory technologies shaped by international organizations, nation-states, market, and globalization processes. Charles Hale calls this regulation the "menace" of neoliberal multiculturalism, arguing that public political commitment to Indigenous and Afrodescendant movements is limited in practice by neoliberal development agendas with "multiple scaled transnational practices and discourses" (Radcliffe 2002, Hale 2005). Hale shows that this form of governmentality reinforces Indigenous identity and cultural demands only to the extent that they do not challenge the State or capitalist structures. "Indios permitidos" are supported, given funding and resources, while "Indios prohibidos" are sanctioned (Hale 2004). More recently, so-called "Pink Tide" States such as Bolivia and Ecuador explicitly recognized Indigenous and Afrodescendant rights in plurinational States, but continued to prioritize damaging extractivist developmental agendas linked to an ideal of a homogenising nation-state (Martinez Novo, forthcoming, Postero 2017).

Thus, despite their mobilization and agency over the last decades and their efforts to transform the political context in which they act (Muteba, 2012), in many parts of Latin America, Indigenous and Afrodescendant movements have faced obstacles developing political spaces that go beyond interpretation and representation (Lefebvre, 1991). As a result, they are often forced to translate themselves and their different and complex ontological understandings of the world in order to counterbalance the hegemonic colonial and patriarchal capitalist spaces that continue to dominate their communities. Mastering other languages, categories, and codes can sometimes lead to effective resistance and successful outcomes, but it can also lead to the expansion and reproduction of colonizing structures. Refusing them through disruption and silence can sometimes promote the reproduction and continual reinvention of worlds, but it can also lead to their marginalization and diminish the chances of democratic participation. As they have since the beginning 
Introduction to the Special Issue | 12

of the colonial era, these groups are negotiating a complex balance of structural forces and political openings.

The papers in this special issue ask: how are these challenges being confronted by Latin American Indigenous and Afrodescendant movements? How are identities fixed and mobilized by the international organizations, States, and the market, and performed or resisted by Indigenous and Afrodescendant communities in order to further their interests and contest or challenge different ontological views? How are these fixed identities expressions of State racism? And how do Indigenous and Afrodescendant movements react to an increasing racist violence coming from the State in the region? How are these movements intersected by multiple oppressions (such as class and gender) beyond ethnicity and race?

\section{Coloniality and the State}

The contributions to this special issue recognize the colonial structures that permeate Latin American societies today. In particular, they analyze cases where State institutions reproduce colonial hierarchies in the way they relate to the nonhuman environment, as well as the way in which Indigenous and Afrodescendant communities, and their ways of knowing and relating to the world, are not only marginalized by State institutions but also actively exterminated; women bearing a disproportionate share of this colonial type of violence.

Julia Zulver shows that the Colombian conflict disproportionately impacted AfroColombian women, and that elements of this violence has its roots in structural and gendered racism that both predates and outlives the armed conflict itself. Based on two groups of Afro-Colombian women living in Bogotá, Zulver's article describes the different strategies that women's organizations take to confront the ongoing kidnappings, assaults, rapes, and femicides in their communities. AFROMUPAZ, displaced women from the Pacific Coast, focus on pyscho-social healing programs based in traditional practices like gardening, initiating business ventures to reduce economic instability, and legally denouncing past and present acts of violence committed against members of the organization (Zulver 2018b). She also considers 
how a more radical new generation of Afro-Colombian feminists - the Colectiva Matamba Acción Afrodiaspórica-whose "empowered female warriors" see racism through an intersectional lens and tackle structural racism head on through targeted and deliberate community engagement activities, such as holding anti-racism workshops, lectures, and cultural activities, as well as monitoring femicide levels in Colombia. Members of these multigenerational organizations learn from the struggles of their elders, and intentionally include their youth in activities of collective healing to create new ways of resistance.

Importantly, Zulver recognizes the ongoing intersecting dynamics of insecurity and violence after the historic signing of a peace agreement between the FARC and the Colombian government in 2016. She highlights the continued violence against social leaders in Colombia, especially Indigenous and Afro-Colombian women, who have been attacked and killed for their social engagement. As mentioned above, more than 350 social leaders have been assassinated in Colombia since 2019. While the systematic violence against social leaders seeks to marginalize the democratic participation of the communities they represent, Zulver recognizes that this type of violence is not merely the result of the Colombian internal conflict. Instead, it responds to historically engrained structural and gendered racism. In the month of June 2020, for example, it was revealed that members of the Colombian military have been involved in the repeated acts of sexual abuse against Indigenous minors. Since many of these violent acts are attributed to State actors, the work of AFROMUPAZ and Colectiva Matamba constitute resistance against gendered State racism.

Therefore, Indigenous and Afrodescendant peoples organize to denounce State violence and colonial hierarchies. They devise ways of healing and protecting themselves from further violence and propose alternative ways of relating to the world. However, cultivating these alternatives is a challenging process. They often clash with the State's interests, language, and categories, which define nature as an object or a resource to be extracted, promote ways of knowing the world that are not rooted in local experiences, and define structural violence as exceptional, reducing reparation from this violence to material compensation. 
In this direction, Yira Lazala examines some of the limitations in the implementation of the 2011 Colombian Act 1448, the Law of Victims and Land Restitution, which have sought to offer reparation to the individuals and collectives affected by the Colombian armed conflict. Based on the case of the Inga Indigenous Community in Aponte Nariño, Lazala argues that the Ingas' understanding of their territory and of the duration of the conflict against their community, reveal temporal and spatial limitations in State's reparation projects. On the one hand, the Inga people do not consider their territory to be limited to the extent of land that is officially recognized by the State. They have argued for the notion of "territory as victim", but the State's notion of territory links indigeneity to an enclosed space. On the other hand, the Inga do not agree with the State's periodization of the conflict, which traces the violence exerted against the Inga to just a few decades ago, beginning with the last phase of the Colombian armed conflict. From the Inga's perspective, the conflict can be traced back to the ancestral past, to Spanish colonization. Rather than seeing their dispossession as a reiterative and persistent phenomenon, the State identifies their dispossession as the result only of the violence resulting from the recent internal war.

The Ingas' understanding of what an integral reparation process would entail reveals further ontological limitations in the way the State reparations are designed. Inga leaders do not conceive reparation as legal remedies or material concessions that are designed as compensations for exceptional periods of violence. Instead, these leaders translate the State's legal concept of reparations into the idea of territorial harmonization, which includes the cultivation of social and spiritual balance. This ontological understanding of territorial harmonization is often not recognized by State institutions. For example, the Inga requests for reparations related to environmental disasters that they understand as the result of social and spiritual imbalance, are often dismissed. Thus, despite national recognition of Indigenous land and reparation rights, ontological tensions as well as temporal and spatial limitations make it challenging for Ingas to gain significant reparation in their own terms.

The denial of Indigenous ontologies by the State is also clear in Thomas Niederberger's contribution. Niederberger traces the endeavor of the Wampis 
nation in the Peruvian Amazon to openly and visibly mobilize nonhuman actors in eco-political struggles. Inspired by the Wampis' uprising against oil extraction in their autonomous lands in the early 2000s, Niederberger shows the ontological clash that characterized the different understanding of the State and the Wampis about the notion of territory: "what for the Wampis was their own territory, the State regarded as limited rights to the land surface."

Niederberger shows how the Wampis decided to abandon western conservationist discourses they had strategically employed as part of a "global ecological imaginary". That model reproduced human exceptionalism by portraying humans as the protectors of a separated and objectified nature. Instead, to reclaim the totality of their land, the Wampis shifted to mobilize different understandings of their integral territory where nonhumans beings are central and cannot be limited to the land surface: "nonhumans cover the entire range of relationships to the territory, including forest, water bodies (abode of tsunki, master of aquatic life), underground (abode of nunkui, mother of edible plants) but also the air and space." Thus, while State notions of territory are based on objectifying views of the environment, and where living relations can be divided through horizontal boundaries, the Wampis reclaim a "vertical territoriality" where living interconnections in all three dimensions are also recognized. For Niederberger, this opens a vertical dimension to the defense of territory - the extension of relationships into the underground and atmosphere - which comes to the fore in parallel with the advancing recognition of nonhumans as right-holders.

\section{Coloniality, the State, and the market}

In the articles described in the previous section, we saw that Indigenous and Afrodescendant groups' ethnic knowledge and practices are often marginalized by (post)colonial State institutions, especially when they are mobilized to protect rights and promote alternative worlds. In this section we consider how market forces profit from the appropriation and commercialization of "ethnic" commodities, such as textiles, art, and music (Comaroff and Comaroff 2009). In some cases, initiatives of benefit sharing and the inclusion of ethnic products in the market are justified as 
a strategy to distribute income to "impoverished" segments of the population. This can be problematic, as it reifies capitalist relations, obscuring forms of wealth that are not measured through mainstream economic indicators. It also portrays the market as the only viable channel for development (Gibson-Graham 2006).

Moreover, the very translation of ethnic products into commodities poses bureaucratic and safety obstacles that effectively block the participation of Indigenous and Afrodescendant communities in the market. When the product reaches the market, it is often sold by someone from outside its community of origin. Thus, the material and knowledge that is necessary to produce a particular ethnic product end up being extracted from local communities, while the benefits are appropriated elsewhere. However, even in cases where local communities manage to overcome market hurdles and sell the product themselves, the commodity form gains prevalence over cultural life. Ethnic products become static and standard commodities with clear markers of cultural "authenticity" demanded by consumers.

Larissa da Silva Araujo's piece on the baianas de acarajé in Brazil provides a case in point. She defines baiana de acarajé as "an Afro-Brazilian craft, performed by autonomous women who work as street vendors of food, such as acarajé (black-eyed pea fritters), abará (steamed peas in a banana leaf), cocada (coconut sweets), among others." In the context of the 2014 football World Cup organized by FIFA, da Silva Araujo examines the process by which the baianas de acarajé, organized as an association, fought for the right to sell their products inside stadiums during football matches, as they have done for decades. Initially excluded from the event by FIFA, the baianas de acaraje organized street protests, mobilized petitions on the internet, and distributed t-shirts to raise awareness about their situation. Acarajé is not just a local specialty food; instead it is part of a food and religious system shared by practitioners of the candomble religion. The baianas de acarajé share these secret crafts with their daughters and kin and offer the food to the warrior deity/orixa Iansã.

While the bainas de acaraje were finally allowed to sell the products during the world cup, da Silva Araujo reflects on the limits of this victory. She argues that state of Bahia's recognition of the baianas de acarajé as part of the state's Intangible 
Heritage was central to FIFA's acceptance of their presence in the World Cup. When international capital arrived to the football events in Brazil, street vendors were forced to find ways of communicating with this type of capital. The notion of cultural heritage proved to be a legible category. However, this category also imposed new commitments on the part of the baianas de acarajé, to perform their art in particular and standard ways suitable to global markets. It traps them into "a static conception of the traditional and the cultural. More importantly, da Silva argues, "they are recognized as subject to the law, but are not recognized as agents of this right. Thus, it is evident that the State dialogues with the "Other" through the code that it created to classify and dialogue with this Other". Like the Ingas described by Lazala and the Wampis described by Niederberger, the Baianas in this case were constrained by the categories of "Otherness" dictated by market forces.

\section{Coloniality and the International system}

Otherness is also built at the international level. The United Nations (UN) has witnessed the presence of Indigenous peoples since 1923, although they were not allowed to participate in UN sessions until 1977. In that year, the International Indian Treaty Council obtained NGO status at the UN. Its first participation in UN session was accompanied by the presence of around one hundred delegates from 15 countries of the Americas. This was a milestone for the international

Indigenous movement in their struggle for land and human rights, as well as nationhood and self-determination. Since the UN had been created to represent nation states at the international level, the Indigenous demand for nationhood and self-determination directly questioned the legitimacy of State borders and authority.

The gathering of multiple and diverse peoples under the notion of "Indigenous" was however not merely the result of Indigenous strategic essentialism. It is a complex term tied to racial colonial classifications, State sovereignty claims as well as to the exoticization of non-Western peoples, still reproduced in national and international fora. Despite the inclusion of Indigenous peoples in the UN, the colonial structure of international bodies is still visible in the codes of conduct, 
languages, and spaces in which Indigenous peoples are expected to participate. Not only are colonial languages such as English, French and Spanish the main ways of communicating at the UN, Indigenous participation is often relegated to thematic areas such as biodiversity and environmental sustainability, extractivism and benefit sharing, as well as traditional knowledge and folklore.

Urpi Saco-Chung uses this type of otherness as a starting point to discuss the notion of "Indigenous" at the UN. While recognizing the rich scholarly debate that seeks to study the notion of Indigenous and indigeneity, Saco-Chung problematizes this notion further. She analyses what the UN expects from Indigenous delegates, the efforts of these delegates to perform these expectations, and the multiple ways in which their identities, knowledges and skills exceeds these limited roles. Her contribution describes the bureaucratic hurdles and social codes that Indigenous delegates need to follow before they can make a statement in the UN. This process does not only include getting accreditation and speaking in an official UN language, but it also includes fulfilling the UN criteria of what it means to be Indigenous. Thus, before Indigenous delegates can even make a statement at the $\mathrm{UN}$, they must engage in a long process of adaptation, accommodation and learning about UN expectations, definitions and codes. Saco-Chung laments that the reverse is less likely to happen. The institutional transformation of the UN to adopt various Indigenous ways of knowing, acting and doing is not a priority, and any change is partial and slow.

Through an ethnographic example about the participation of a Guarani-Kaoiwá woman from Matto Grosso do Sul, Brazil, Saco-Chung illustrates what happens when the performance of the Indigenous category goes beyond UN definitions and expectations. In her description, Saco-Chung focuses on the tension created in a UN auditorium by the evident discomfort of this woman when reading a statement in Spanish, one of the UN official languages. Saco-Chung shows that the choice of this woman to face discomfort by going off script and speaking instead in a nonofficial language, reveals aspects of the Indigenous category that do not fit with the fixed notions of the UN. This decision destabilized the ways of doing in the UN, as interpreters and translators struggled to capture what this Indigenous delegate was trying to communicate. 
Instead of putting the burden on the Guarani-Kaoiwá woman for not adapting to the codes of the UN, Saco-Chung prefers to ask what this performance of the Indigenous category reveals. It is not just a matter of languages. Her speaking in Portuguese, instead of reading in Spanish, changed the content and form of her presentation. It showed not that this woman would not comply to the codes of the international institutional setting, but rather that she could do that, do more, and do it in different ways, while the UN struggled to accommodate. Thus, through a simple ethnographic example, Saco-Chung reveals the disciplinary and exclusionary structures of international organization codes and languages, as they reduce the Indigenous category to their own terms and knowledges.

\section{Decolonial initiatives}

Seeking to build bridges between different ways of producing knowledge we invited an Indigenous organization from Colombia to write a piece about their experience dealing with dominant categories. The Pijao Group was created by university students from the south of Tolima in Colombia, who self-identify as Indigenous. One of us, Diego Silva, had had the opportunity to meet some of its members while carrying out research about cotton production in their territories. As part of this research, Diego had joined an agroecology school organized by the environmentalist NGO Grupo Semillas, where he met some local youth who were part of the Pijao Group. Sometimes the leaders of this group also joined the school actively voicing their opinion about the local struggle of their ancestors for land rights and for the right to autonomously govern their territory.

The piece that the Pijao Group wrote for this issue reads as a poetic chronicle about the growth of the group. The writing is, however, much more than that. It is a reflection on the coloniality of the mind of local youth, a register of their transgressions to escape the expectations of western society, and story of selfrecognition and revalorization as Indigenous youth.

Viviana Lozano Ducuara and Edwin Alexander Henao Conde write about their experience as founders of the Pijao Group, an Indigenous youth organization from 
the Coyaima and Natagaima peoples of the south of Tolima in Colombia. Through the metaphor of a corn seed that is planted, germinates and produces grain, these two Indigenous activists/social scientists go back to 2015 when the group was founded, to tell the story of how the Pijao Group has progressed and impacted their communities.

Funded by university students from the Universidad Nacional in Bogotá, the Pijao Group organized workshops to prepared high school students in the south of Tolima for the State education quality tests, and for public universities entry exams. The objective was to give the local youth the opportunity, through higher education, to design life-projects that went beyond becoming a soldier, a farmer, or a care worker in the city. However, the workshops rapidly expanded beyond the State curriculum to include cultural activities such as hikes and rituals so that participants could recognize and value their territory, tradition, and customs. Recognizing that most education in their territories was a form of recolonization, they sought to accompany their fellow students to alternative worlds.

The Pijao group is a conscious project of self-recognition and decolonization of the mind, of knowledge, and language. Naming and speaking in their own terms is central to the Pijao Group. Their workshops were named "Weaving Knowledges for Life", the hikes throughout the Indigenous territory were called "Pijao Paths", and the discussions held in the Group's headquarters were called "Speaking Pijao". Since the Pijao language has been largely lost, the act of naming their world, recompiling their ancestors terms, and promoting their words is an effort to revive and re-value their Indigenous identity. They sought to create a "horizontal field between those who teach and those who learn" in which the group could carry out politics through the Indigenous practices of everyday life.

Through their commitment, the Pijao Group has made itself noticeable among other local organizations. Importantly, they do not define themselves as another Indigenous group, but as an ally where the youth of the community, the children of members from different organizations, can find their own space. This has allowed the Pijao Group to fight for a voice in the local discussions between Indigenous leaders and State officials to devise ways in which the Pijao's future can be protected. They conclude: "The decolonization of thought, identity and language 
in the midst of consumerism and exploitation must be remembered and promoted in our daily lives. Thus, one of the most important lessons guiding our sowing and harvesting is to bring politics into every aspect and field of life."

\section{Indigenous and Afrodescendent participation: Power, Politics, and the Spaces in Between}

In "From participation to power" Christopher Kelty $(2012,24)$ differentiates between two questions related to forms of participation: first, what kinds of participatory structures do organizations, movements, or governments create? and second, how does participation affect or transform the structures of participation? The Indigenous and Afrodescendant movements and organizations discussed by the contributors to this special issue help us to reflect on these questions. The State, the market, the university, and the international organizations all structure participation in ways that are functional to late capitalism. In contrast, Indigenous organizations described by our contributors, such as the Wampi and the Inga nations, as well as Afro- Colombian women's organizations and Indigenous youth groups, create other very different types of participatory structures often defined as the "Other" by the first set of dominant organizations.

By exploring the codes, languages and categories by which these organizations function, the contributions to this issue shed light on the types of participatory structures that they create. For example, AFROMUPAZ and Colectiva Matamba create spaces of healing, memory building, economic solidarity, and resistance to State racism; the baianas de acaraje struggle to reproduce the market as a space of economic resilience and cultural expression; while the Pijao Group translates hikes, workshops and language into spaces of identity building and construction of life projects.

Moreover, by exploring the tensions and clashes between dominant and subaltern participatory structures, the contributions to this issue illustrate how Indigenous and Afrodescendant movements participate in and negotiate dominant structures of participation (the State, the market, the UN) and struggle to change them. For 
instance, the Wampis refuse to adopt the State's ontological understandings of human-environment relations, pushing back with their notion of "vertical territoriality". The Inga refuse to accept the State's notion of reparation and the State's temporalities of the violence inflected upon their communities, instead holding fast to the longer-term notions of colonial harm. The Indigenous delegate to the UN goes off script and speaks in a language that the International Institution cannot - or will not --understand.

Ultimately, participation is about power (Kelty 2012, 29). Indigenous and AfroColombian movements and organizations create spaces of participation seeking to fulfill different goals. Some of them will be directed at satisfying collectively recognized internal needs, such as providing support in economic, psychological, emotional and security areas. Other efforts are directed outwards, in relationship to dominant structures of participation where they have struggled to participate. As their internal codes, categories, ontologies and languages clash with dominant ones, they try to modify dominant structures so that they can participate in them without giving up their ways of knowing, doing and living.

This is the site of Indigenous politics. French theorist Jacques Ranciere (1999) defines "politics" as "disagreements" intended to call attention to inequality. He opposes politics to "policing", the structures that organize society such that some people-"the part without a part" - are not visible within the "partition of the sensible" (2001). For Ranciere, politics erupts in that rare moment when those excluded from the existing social order (or who are invisible and inaudible in its current aesthetic distribution) rise up, make themselves visible, and through disagreement, call attention to the "scandal" of their invisibility. For centuries, Indigenous and Afrodescendant peoples have been in this category, their languages and customs considered "noise", to use another of Rancière's terms. Following Ranciere, we can characterize the efforts our contributors describe as disagreements that dispute the relegation of Indigenous and Afrodescendants to this category. These disagreements are acts of emancipatory politics, enacting equality by requiring the police order - the university, the UN, the market-to take them into account. 
It is however not just a matter of seeking inclusion into existing structures but about changing the police order itself. For example, Marisol de la Cadena (2010) has challenged the branding of Indigenous struggles in Latin America as "ethnic politics:" "a quest to make cultural rights prevail". Instead, through the recognition of non-humans as actors in Indigenous politics, the notion of "cosmopolitics" suggests a way in which Indigenous peoples' relations to their environment can expand and defy the participation structures where Indigenous peoples are taken into account. Another example is the Inga's notion of reparation for the past and current violence exerted against their communities in Colombia (see Lazala in this issue). For the Inga, the State's recognition of their communities as victims of the Colombian conflict, and who are entitled to reparations, is not an end product. Instead, they use their inclusion into the State's participatory spaces to change the very categories and definitions structuring their participation.

Of course, disagreements are often met with resistance. As Indigenous and Afrodescendant people challenge the colonial structure of dominant organizations, the State responds through violence and extraction of natural resources, the market forces commodify cultural expressions in ways that detach products and consumers from producers, and the university gives entry to marginalized communities without taking account of their knowledges and histories in their curricula. Although progress has been made in some cases on the State's recognition of the rights of nature, Indigenous land rights, and legal inclusion, for the most part, it has been carried out on the State's terms, as the literature on neoliberal multiculturalism described above points out.

Yet, politics is not only waged in a dualistic or contested way. As many of the forms of disagreement described in this volume demonstrate, politics is often carried out in the "spaces in between" hegemonic structures, logics, and sovereignties (see Postero and Fabricant 2019, 114). Precisely because they are struggling against powerful discourses and institutions, Indigenous and Afrodescendant peoples are forced to carry out complex negotiations with more powerful actors, using their languages at times, and in others, taking advantage of the ambiguities that exist with relation to the categories they are supposed to inhabit, asserting their own visions for the future. Negotiating meaning in spaces of uncertainty and 
contention, these savvy political actors enact a "camouflaged form of politics", smuggling in their own notions of autonomy, self-governance, sovereignty, and cosmovisions (Ibid).

Inhabiting these spaces in between also prepares groups for action when the political conjunctures change. We mentioned at the beginning of this introduction that since these articles were written, there has been a wave of mobilizations and civil society uprisings. In Bolivia, Indigenous president Evo Morales resigned in November 2019 after massive protests and street violence following allegations of electoral fraud. In Chile, civil society erupted in 2019 for very different reasons: the costs of neoliberalism became ever clearer after metro fares were raised. In 2019, public outrage grew as massive fires burned across the Amazon due in large part to continued expansion of the agricultural frontier. Moreover, social leaders in Colombia continue to be threatened, intimidated and often assassinated. In 2019 Colombia was considered the country with the highest number of environmentalist leaders assassinated in the world. Many of these leaders are part of Indigenous and Afrodescendent communities who oppose the extraction of natural resources from their territories (Grueso 2012, 367).

In these new conjunctures, Indigenous and Afrodescendant organizations have complemented what Gramsci would call their "wars of position" with more active "wars of maneuver" (Gramsci 1985). In Colombia, for example, Indigenous communities have actively worked to position their territories as victims of the national conflict (Ruiz 2017) and Afrodescendant communities have proposed local programs of territorial development based on the conservation of local habitats (Grueso 2012, 367). In Peru Indigenous communities have sought to redefine the notion of territory based on their cosmovisions to include underground natural resources (Niederberger, in this issue). In Colombia, Ecuador and Bolivia legislation has been developed that recognizes the rights of nature, although this type of recognition remains largely rhetorical (Kotzé and Villavicencio Calzadilla 2017). These are efforts towards redefining the frameworks that are used in their territories to govern the relations between humans and their environments, and a step towards reclaiming autonomy in the governance of their territories. The ongoing work of these groups to position their cosmovisions and categories at the national and 
international levels allows them to mobilize their categories when opportunities for social mobilization emerge. In particular, Indigenous notions have been widely used by social movements in Latin America in rejection of mining projects in Ecuador (Sánchez-Vázques, Leifsen, and Vérdu 2017), seed confiscations in Colombia (Silva and Gutierrez 2020), and the privatization of natural resources in Bolivia (Burguete 2017), to name just a few. In this way, "wars of position" prepare the ground for more effective "wars of maneuver."

Yet, actively engaging in wars of maneuver is extraordinarily difficult, and risks shutting down the possibilities of negotiating the ambiguous spaces in between. For instance, in Bolivia, tensions between different Indigenous groups had long been simmering, despite the fact that its president was Indigenous and its 2009 constitution purported to establish new rights for Indigenous peoples. Many highland Andean Indigenous people supported president Morales and greatly benefitted from his development program based on natural resource extractivism, especially the newly emerging urban Indigenous middle class and Indigenous cocagrowers. But many lowland Indigenous peoples strongly opposed Morales, whom they saw as willing to sacrifice their lands and livelihoods for the country's "economic liberation" (Postero 2017).

A significant number of highland Aymara had also begun to oppose Morales, arguing his reforms were merely superficial and failed to support Indigenous legal systems and collective projects (Copa Pabón 2018). For many years, these various Indigenous opponents had no choice but to negotiate with Morale's powerful MAS party, using whatever political openings they could to push for their long-term strategic goals of autonomy. When Morales's political fortunes were challenged in 2019, however, many Indigenous people refused to support Morales, allying instead, with the mestizo middle class groups opposing Morales (Portugal Mollinedo 2020). This led to horrifying violence, especially after Right-wing Jeannine Añez took over as interim President.

What the 2019 political crisis points out is that the many Indigenous people in Bolivia have very heterogeneous positions vis-à-vis the State, democracy, and indigeneity. This reminds us that the very category of indigeneity is constructed, taking shape in particular moments and places (see Postero 2013; Cadena and Starn 
2007). While the Morales government had tried to foment and perform a unified ideal of indigeneity, in practice the plurality of Indigenous positions and interests contributed to his downfall. Clearly, as Silvia Rivera Cusicanqui (2019) clarifies, this does not mean that democracy has been reestablished in Bolivia, as labor unions, leftist groups and Indigenous groups are still traversed by intersectional inequalities. Thus, Cusicanqui calls for a further pluralization of Indigenous voices that brings together groups of women and men from different communities and ages to continue the anticolonial struggle in Bolivia. She describes this plurality with the Aymara term, ch'ixi, a concept that goes beyond hybridity to recognize "the complex mediations and heterogeneous constitution of our societies" (2018:17). By arguing that "el mundo ch'ixi es possible" (the ch'ixi world is possible), Rivera Cusicanqui suggests that the ruptures that can divide a society can also be important resources, forging an "ethical compass" that guides society to "planetariness, solidarity, recognition of differences, respect", and (citing Rancière) "the equality of intelligences". (Ibid: 80)

In contrast, strategic essentialism has been key for Colombian Indigenous and Afrodescendant peoples. Indeed, mobilization around identity has resulted in constitutional changes that grant these communities with special rights to land, economic projects and education. It can be argued that strategic essentialism around identity politics in Colombia has been so successful that rural populations that do not self identify, or are not recognized by the State, as "sufficiently" Indigenous or Afro-Colombian are at a disadvantage (Bocarejo 2011). Since these categories are largely defined by the State, some populations are excluded from sharing the benefits of collective victories. At the same time, these categories continue to provide a space of participation from which marginalized groups can voice their needs. Thus, some rural communities seek to recover, cultivate and manufacture their identities as Indigenous and Afrodescendant. However, as reflected by the increasing number of assassinations of Indigenous and Afrodescendant leaders, the success of these groups in organizing around particular identities, projects and ideas is threatening for extreme right wing factions and criminal organizations that seek territorial control in Colombia.

Indigenous and Afrodescendant groups mobilize their identity strategically while 
remaining open to working the "in-between" spaces and seeking outside support. This does not only refer to the indigenization of rural communities, but also the construction of social and political networks with allies who recognize their collective identity and claims to local practices and territories (Grueso 382). Thus, while identity categories can become oppressive when they are mobilized for the benefit of particular groups. Also, as we saw in Bolivia, they also provide strategic spaces of participation and emancipation where disagreements can be voiced. Just as there is no need to choose between "wars of position" and "wars of maneuver", there is no need to choose between pluralism and strategic essentialism when the goal is simultaneously to be included and to transform existing spaces of participation, to create new evolving ones. What is important is to maintain a critical perspective on the particular moments, spaces and forms in which categories are mobilized (including identity categories), as well as on the relational ways in which dominant/subaltern categories are continuously built, resisted and negotiated within and outside Indigenous and Afrodescendant groups.

\section{References}

Bocarejo Diana. 2011. "Dos paradojas del multiculturalismo Colombiano: La especialización de la diferencia Indígena y su aislamiento político." Revista Colombiana de Antropología. 47(2): 97-121

Burguete, Araceli. 2007. "De la resistencia al poder. Articulación y repertorios indígenas en la lucha por el poder político: el ensayo boliviano.” Argumentos 20(55).51-73.

Cadena, Marisol de la. 2010. "Indigenous cosmopolitics in the Andes: conceptual reflections beyond 'politics." Cultural Anthropology 25 (2): 334-70. https://doi.org/10.1111/j.1548-1360.2010.01061.x.

Cadena, Marisol de la, and Orin Starn. 2007. Indigenous experience today. Oxford; New York: Berg. http://site.ebrary.com/id/10233374.

Comaroff, John L., and Jean Comaroff. 2009. Ethnicity, Inc. Chicago studies in practices of eaning. Chicago: University of Chicago Press. 
Introduction to the Special Issue | 28

Copa Pabón, Magali Vienca, 2018. "Paradojas de la autonomía"indigena" en Bolivia," Pukara Periódioc Mensual, Diciembre 2018, Qollasuyu, Bolivia, Año12, No 148. www.periodicopukara.com.

Cottrol, Robert J. y Tanya Kateri Hernandez (2001): "The role of law and legal institutions in combating social exclusion in Latin American countries: AfroAmerican populations". Conference read at the Inter-American Development Bank Conference Towards a Shared Vision of Development: High-Level Dialogue on Race, Ethnicity and Inclusion in Latin America and the Caribbean, June 18, 2001, in Washington, D.C.

http://www.iadb.org/exr/events/conference/socialinclusion.htm

Cusicanqui, Silvia Rivera. 2018, Un mundo ch'ixi es posible. Ensayos desde un presente en crisis. Ciudad Autónoma de Buenas Aires: Tinta Limón.

2019. "What is democracy? What is being Indigenous?" presented at the Parlamento de la Mujer, Bolivia, December 11.

https://www.youtube.com/watch?v=z-CjK7ZW6BA\&t=263s.

Gibson-Graham, Julie Katherine, 2006. A postcapitalist politics. Minneapolis: U of Minnesota Press.

Gramsci, Antonio. 1985. Selections from the prison notebooks of Antonio Gramsci. Translated by Quintin Hoare. 8. pr. New York: International Publ.

Grueso, Libia. 2012. "Representaciones y relaciones en la construcción del proyecto político y cultural del proceso de comunidades negras en el contexto del conflicto armado en la región del Pacífico Sur Colombiano." In Antropología y Desarrollo: Discurso, Prácticas y Actores, edited by Beatriz Pérez Galán, 366-85. Catarata 406. Madrid: Los Libros de la Catarata.

Hale, Charles, 2004. "Rethinking indigenous politics in the era of the 'indiopermitido'". NACLA Report on the Americas, 38(2), 16-21.

Hale, Charles R. 2005. "Neoliberal multiculturalism." PoLAR: Political and Legal Anthropology Review 28 (1): 10-19.

https://doi.org/10.1525/pol.2005.28.1.10. 
Kelty, Chris. 2012. "From participation to power." In The Participatory Cultures Handbook, edited by Aaron Delwiche and Jennifer Jacobs Henderson, 1st ed., 2231. Routledge. https://doi.org/10.4324/9780203117927.

Kotzé, Louis J., and Paola Villavicencio Calzadilla. 2017. "Somewhere between rhetoric and reality: Environmental constitutionalism and the rights of nature in Ecuador." Transnational Environmental Law 6 (3): 401-33. https://doi.org/10.1017/S2047102517000061.

Martinez Novo, Carmen, forthcoming, Undoing multiculturalism: turn to the left, resource extraction and the decline of Indigenous rights in Ecuador. Pittsburgh: University of Pittsburgh Press.

Muteba Rahier, Jean (2012): Black social movements in Latin America. From monocultural mestizaje to multiculturalism. New York: Palgrave

Portugal Mollinedo, Pedro, 2020. Por qué colapsó el MAS, Pagina Siete, Bolivia. June 29, 2020. https:/www.paginasiete.bo/opinion/2020/7/29/por-que-colapso-elmas-262729.html\#

Postero, Nancy. 2013. "Introduction: Negotiating Indigeneity." Latin American and Caribbean Ethnic Studies 8 (2): 107-21

https://doi.org/10.1080/17442222.2013.810013.

Postero, Nancy, and Nicole Fabricant. 2019. "Indigenous sovereignty and the new developmentalism in plurinational Bolivia." Anthropological Theory 19 (1): 95-119. https://doi.org/10.1177/1463499618779735.

Postero, Nancy Grey. 2017. The Indigenous state: race, politics, and performance in plurinational Bolivia. Oakland, California: University of California Press.

Lefebvre, Henri (1991) [1974]: The Production of space. Oxford: Blackwell.

Radcliffe, Sarah; Laurie, Nina; Andolina, Robert (2002): "Indigenous people and political transnationalism: globalization from below meets globalization from above?" WPTC-02-05 Project "Transnational indigenous communities in Ecuador and Bolivia”

http://www.transcomm.ox.ac.uk/working\%20papers/WPTC-02-

05\%20Radcliffe.pdf 
Introduction to the Special Issue | 30

Rancière, Jacques. 1999. Disagreement: politics and philosophy. Minneapolis: Univ. of Minnesota Press.

Rancière, Jacques, Davide Panagia, and Rachel Bowlby, 2001. "Ten theses on politics." Theory \& event 5.3. https://muse.jhu.edu/article/32639/summary

Ruiz, Daniel. 2017. “'El territorio como víctima. ontología política de las leyes de víctimas para comunidades indígenas y negras en Colombia.'” Revista Colombiana de Antropología 53 (2): 85-113.

Sánchez-Vázques, Luis, Esben Leifsen, and Ana Vérdu. 2017. "Minería a gran escala en Ecuador: conflicto, resistencia y etnicidad." Revista de Antropología Iberoamericana 12 (2): 169-92.

Silva and Gutierrez. 2020. "Revolturas: resisting multinational seed corporations and legal seed regimes through seed-saving practices and activism in Colombia.” Journal of Peasant Studies. 47(4): 674-699

Seider, Rachel, 2002. Multiculturalism in Latin America. (2002). NY: Palgrave Mcmillan

Van Cott, Donna Lee, 2000. The friendly liquidation of the past: the politics of diversity in Latin America. University of Pittsburgh Press.

Zulver, Julia. 2018b. High risk feminism in Colombia: Women's mobilisation in violent contexts [DPhil Thesis]. University of Oxford.

https://ora.ox.ac.uk/objects/uuid:3fc50c53-d6f5-49c9-a3ba-ca68570a78a3. 